\title{
Dobór wydajności gazów propan-butan dodawanych w celu wspomagania efektywnego spalania gazu ziemnego niskometanowego z użyciem flary
}

\author{
How to select the flow rate of propane-butane for the effective burning of natural gas with \\ low methane content using a flare
}

\author{
Paweł Budak, Tadeusz Szpunar \\ Instytut Nafty i Gazu - Państwowy Instytut Badawczy
}

\begin{abstract}
STRESZCZENIE: W artykule omówiono zagadnienie spalania gazu ziemnego (będącego mieszaniną gazów) przy użyciu flary w przypadku dużej zawartości w nim składników niepalnych, takich jak azot, hel, dwutlenek węgla itp. Spalanie takich mieszanin we flarze wymaga na ogół wzbogacenia składu mieszaniny przez doprowadzenie do strumienia gazów kierowanych do spalenia dodatkowego strumienia gazów palnych, tak aby skład mieszaniny mieścił się powyżej dolnej granicy palności/wybuchowości. W Polsce do gazów wymagających takiego wzbogacania należy m.in. gaz ze złoża Cychry oraz Sulęcin, w którym zawartość składników niepalnych (azotu) wynosi powyżej 90\%, a udział składników palnych jest niski. Zapewnienie całkowitego spalania mieszaniny gazów jest szczególnie istotne w przypadku obecności w niej siarkowodoru, który jest gazem trującym i który należy bezwzględnie zutylizować. Wzbogacenie mieszaniny gazów odbywa się przez wprowadzenie do strumienia gazów kierowanych do flary dodatkowych ilości gazu, na ogół propanu-butanu lub innych gazów palnych. W artykule przedstawiono typową konstrukcję urządzenia do spalania mieszanin gazów stosowanego w przemyśle petrochemicznym i naftowym oraz omówiono przeznaczenie typowych części składowych instalacji. Podano zależność empiryczną pozwalającą na ustalenie palności mieszaniny gazów o podanym składzie zawierającej gazy palne i niepalne. Przedstawiono również algorytm obliczeniowy pozwalający na podanie natężenia przepływu gazu propan-butan, który należy doprowadzić do strumienia gazów, aby mieszanina mogła być efektywnie spalona we flarze. Zaprezentowano wyniki obliczeń dla gazów z dużą zawartością azotu, pochodzących z czterech polskich złóż. Przedstawiony sposób ustalania palności mieszanin gazów lub jej braku oraz natężenia przepływu gazów propan-butan wymaganego do całkowitego spalania tej mieszaniny oparty jest na zależnościach empirycznych i może być pomocny przy planowaniu wspomaganego spalania gazu ziemnego (nienadającego się do zagospodarowania) przy użyciu flary w celu jego utylizacji.
\end{abstract}

Słowa kluczowe: gaz ziemny, wartość opałowa, ciepło spalania, górna/dolna granica palności, świeca, mieszanina gazów propan-butan.

\begin{abstract}
The paper discusses the problems related to the burning of gas mixtures containing flammable and non-flammable gases using a flare. Before being burned, such a gas mixture must be "enriched" with other flammable gases before it can be directed to the flare. In the case of some Polish gas reservoirs such as Cychry or Sulęcin, the composition of the gas mixture doesn't make it possible to burn it using the flare because the content of inflammable components is too high and the gas mixture is inflammable. The gas from the reservoirs mentioned above contains above 90 percent of nitrogen and small percentages of flammable components. Sometimes, besides nitrogen, the gas mixture contains other inflammable gases like carbon dioxide, helium, and oxygen. Usually, the propane/butane is used for that purpose. The possibility of burning the gas mixture using the flare is particularly important if the toxic gases are present in the mixture - hydrogen sulfide in particular. The propane/butane gases are added to the stream of gas mixture meant for burning using a special appliance. The typical arrangement of a gas-burning installation (i.e. the flare) is shown and the destination of its components is discussed. The empirical formula is provided which allows us to recognize if the gas mixture is flammable or not. The composition of the gas mixture must be known to calculate the propane/butane flow rate, including percentages of flammable and inflammable components. The algorithm constructed for calculating the propane/butane flow rate is presented, which must be maintained to assure the flammability of the gas mixture destined for burning using the flare. The results of the calculations for four gas mixtures from the Polish gas reservoirs are provided. The presented method of determining the flammability of gas mixtures (or its inability to be burned) and the flow rate of the propane/butane mixture required for complete combustion is based on empirical relationships, which are provided in the paper and may be helpful in planning the assisted combustion of low methane gases (not suitable for further use) using a flare.
\end{abstract}

Key words: natural gas, heating value, calorific value, low/high flammability limits, flare, propane/butane mixture.

Autor do korespondencji: P. Budak, e-mail: pawel.budak@inig.pl

Artykuł nadesłano do Redakcji: 28.09.2020 r. Zatwierdzono do druku: 11.01.2021 r. 


\section{Wprowadzenie}

Podczas eksploatacji złóż ropy naftowej odbierany gaz ziemny spalany jest na ogół na flarze, to jest specjalnym urządzeniu stosowanym w kopalniach węglowodorów, a także w rafineriach, zakładach chemicznych i petrochemicznych. W zakładach chemicznych i petrochemicznych spalanie gazu odbywa się na pewnej wysokości nad powierzchnią terenu w tzw. zestawie flary, do którego gaz dopływa okresowo w przypadku nadmiernego wzrostu ciśnienia w linii technologicznej w wyniku działania ciśnieniowego zaworu nadmiarowego.

Olbrzymia większość gazu spalana jest jednak w przemyśle naftowym, kiedy podczas eksploatacji ropy wydobywane są pewne ilości gazu ziemnego. W przypadku braku odpowiedniej infrastruktury, takiej jak system rurociągów do odprowadzania gazów w celu wykorzystania przemysłowego, są one spalane na miejscu w pionowych zestawach flary lub na powierzchni we wgłębieniach terenu.

Spalanie gazu ziemnego w atmosferze pozwala na jego utylizację w razie braku możliwości innego sposobu zagospodarowania, z tym że rozwiązanie takie stanowi jednak zagrożenie dla zdrowia ludzi i przyczynia się do wzrostu ilości dwutlenku węgla w atmosferze. Ponadto w przemyśle petrochemicznym gaz po spaleniu na flarze może nadal zawierać lotne substancje, takie jak dwutlenek siarki i inne związki siarki, o których wiadomo, że mogą być przyczyną astmy oraz innych chorób układu oddechowego. W spalanym gazie ziemnym mogą występować węglowodory aromatyczne, takie jak benzen, toluen, ksylen oraz benzopiren, będące związkami rakotwórczymi. Spalanie gazu ziemnego, którego zagospodarowanie jest nieopłacalne ekonomicznie, jest najczęściej stosowanym sposobem jego utylizacji.

Według danych za rok 2011 podanych przez The World Bank (Szczypiorska, 2015) ilość gazu ziemnego spalanego w ramach utylizacji w całym przemyśle światowym wyniosła 150 miliardów normalnych metrów sześciennych rocznie, co odpowiada 25-30\% rocznego zużycia gazu w Stanach Zjednoczonych i Unii Europejskiej, przy czym 10 krajów odpowiada za spalanie $72 \%$ tej ilości gazu. $Z$ wymienionej objętości gazu najwięcej przypada na Federację Rosyjską (27\%), a w dalszej kolejności najwięcej gazu spalane jest w Nigerii (11\%), Iranie (8\%), Iraku (7\%), USA (5\%), Algierii (4\%), Kazachstanie (3\%), Angoli (3\%), Arabii Saudyjskiej (3\%) i Wenezueli (3\%)

(Yaws i Braker, 2001; Chilcoat, 2013). Spalanie gazu wydobywanego wraz z ropą na polach naftowych jest źródłem znacznej emisji dwutlenku węgla. Rocznie w wyniku spalania gazu w przemyśle naftowym do atmosfery dostaje się 400 milionów ton dwutlenku węgla, co stanowi 1,2\% światowej emisji tego gazu do atmosfery. Obecnie obserwowany jest trend spadkowy ilości spalanego gazu ziemnego. W latach 2005-2010 spadek ten wyniósł 20\%, przy czym największy był w Federacji Rosyjskiej (Yaws i Braker, 2001; Szczypiorska, 2015).

\section{Typowe elementy zestawu flary do spalania gazu}

Na rysunku 1 pokazano typową instalację zestawu flary pionowej do spalania gazu, stosowaną w przemyśle petrochemicznym. Flary używane w przemyśle naftowym mają konstrukcję bardzo podobną lub identyczną.

układ doprowadzania pary wodnej

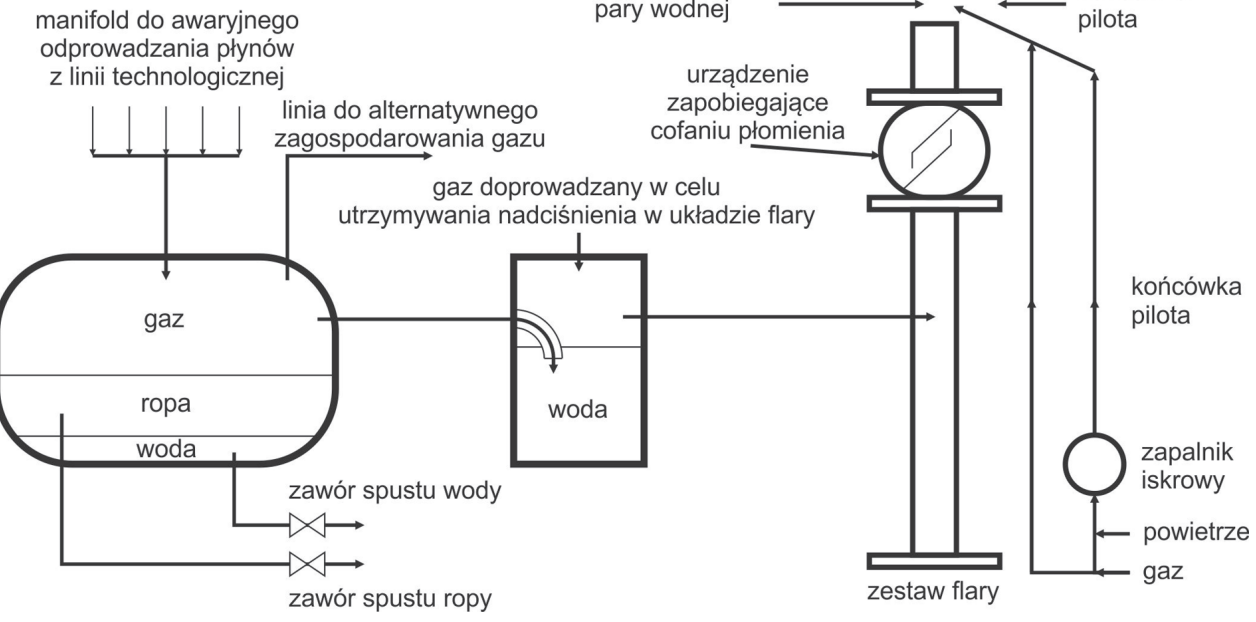

Rys. 1. Instalacja pionowego zestawu flary do spalania gazu w zakładach petrochemicznych

Fig. 1. Installation for burning gas mixtures used in the petrochemical industry

W przypadku wzrostu ciśnienia w linii technologicznej ponad założoną wartość następuje otwarcie ciśnieniowego zaworu nadmiarowego oraz odprowadzenie gazów i pewnej ilości cieczy do zbiornika separatora, skąd gaz kierowany jest poprzez układ przewodów do pionowego zestawu flary, w którym jest spalany na jej wylocie. Wielkość oraz jasność płomienia zależą od wydatku przepływu gazu, jego rodzaju oraz wartości opałowej (wartości ciepła spalania). Większość zestawów flary wyposażona jest w separator, gdzie następuje oddzielenie gazu od cieczy. W celu ograniczenia dymienia do strumienia spalanego gazu wprowadzana jest pewna ilość pary wodnej. Na wylocie pionowego zestawu flary instalowany jest „pilot”, w którym pewna niewielka ilość gazu ulega spalaniu w sposób ciągły, tak aby w przypadku nagłego zrzutu gazu z linii technologicznej jego zapłon był natychmiastowy. W zestawie flary instalowane jest również zabezpieczenie przed cofaniem 
się płomienia w postaci zbiornika z wodą i syfonem. W przypadku flar instalowanych w przemyśle naftowym konstrukcja zestawu do spalania gazu ziemnego jest niemalże identyczna. Jak widać z rysunku 1, głównymi elementami zestawu flary są:

- $\quad$ separator, w którym następuje rozdział gazu od wody i ropy;

- zbiornik wyrównawczy (water seal drum), do którego doprowadzany jest gaz o ciśnieniu wyższym od panującego w układzie spalania w celu zapobieżenia dostawaniu się powietrza do wnętrza układu;

- układ odprowadzania gazu w celu jego alternatywnego zagospodarowania;

- układ doprowadzania pary wodnej do wylotu flary w celu zmniejszenia dymienia;

- $\quad$ pilot wraz z układem zapłonowym zapewniającym natychmiastowy zapłon gazu;

- urządzenie zapobiegające cofaniu się płomienia od wylotu flary.

W przypadku flar używanych w przemyśle naftowym nie wszystkie wymienione urządzenia są instalowane, natomiast mogą pojawić się dodatkowe instalacje, na przykład urządzenia do doprowadzania dodatkowych ilości gazu palnego w celu poprawy efektywności spalania lub zapewnienia możliwości spalania w ogóle, co może wystąpić w przypadku, gdy spalany gaz ziemny zawiera dużą domieszkę gazów niepalnych, na przykład azotu. Spalanie takiego gazu może wymagać wspomagania, do czego służy dodatkowa instalacja doprowadzająca gaz palny - na ogół propan-butan - do końcówki flary.

\section{Mieszaniny gazów}

Gazy można zakwalifikować do jednej z trzech grup:

- oksydantów;

- gazów obojętnych (niepalnych);

- gazów palnych.

Do najbardziej popularnych oksydantów należą tlen oraz chlorki, które same w sobie należą do gazów niepalnych, ale działają jako utleniacze wspomagające spalanie. Gazy obojętne są niepalne i niekiedy stosuje się je w systemach gaśniczych. Przykładami gazów obojętnych są dwutlenek węgla, hel, azot, argon, neon i ksenon. Przez gaz palny rozumiemy taki, który łatwo ulega zapaleniu i proces spalania jest kontynuowany, jeżeli zapewniony jest dopływ utleniacza. W tabeli 1 podano zestawienie gazów palnych najczęściej występujących w gazie ziemnym (Molnarne et al., 2005; Schröder i Molnarne, 2005). Do podstawowych pojęć dotyczących gazów palnych należą:

- zakres palności (lub zakres wybuchowości) - jest to zakres zawartości danego gazu w powietrzu, w którym będzie się on spalał (lub wybuchnie) w przypadku kontaktu ze źródłem ognia. Jeżeli zawartość gazu palnego w mieszaninie z powietrzem jest poniżej zakresu palności, oznacza to, że jest ona zbyt uboga, aby uległa spaleniu (lub była zdolna do wybuchu), a jeżeli zawartość gazu jest powyżej górnej granicy zakresu palności (wybuchowości), to mieszanina danego gazu z powietrzem jest zbyt bogata, aby mogła ulec spaleniu; - górna i dolna granica zakresu palności (wybuchowości) powszechnie oznaczane są w literaturze światowej jako LEL (lower explosive limit) / LFL (lower flammable limit) (dolna granica zakresu wybuchowości/palności) i UEL (upper explosive limit) / UFL (upper flammable limit) (górna granica wybuchowości/palności). Zdaniem specjalistów granice zakresów palności i wybuchowości są pojęciami równoznacznymi (Molnarne et al., 2005; Schröder i Molnarne, 2005; Bertolino et al. 2019).

Tabela 1. Zestawienie składników palnych najczęściej występujących $\mathrm{w}$ gazie ziemnym oraz ich granice palności

Table 1. The most common components of natural gas mixture and their flammability limits

\begin{tabular}{|l|c|c|}
\hline \multirow{2}{*}{\multicolumn{1}{|c|}{ Gaz }} & LEL/LFL & VEL/VFL \\
\cline { 2 - 3 } & \multicolumn{2}{|c|}{ (\% obj. względem powietrza) } \\
\hline \hline Metan & 5,00 & 15,00 \\
\hline Etan & 3,00 & 12,40 \\
\hline Propan & 2,10 & 10,10 \\
\hline Butan & 1,86 & 8,41 \\
\hline Izobutan & 1,80 & 8,44 \\
\hline Pentan & 1,40 & 7,80 \\
\hline Izopentan & 1,32 & 9,16 \\
\hline Heksan & 1,10 & 7,50 \\
\hline Siarkowodór & 4,30 & 4,60 \\
\hline
\end{tabular}

Do określania dolnej i górnej granicy zakresu palności mieszaniny gazów palnych w literaturze niemieckiej podawane są następujące zależności (Molnarne et al., 2005; Schröder i Molnarne, 2005):

$$
L E L_{\text {mieszaniny }}=\frac{\sum_{i=1}^{N} P_{i}}{\sum_{i=1}^{N} \frac{P_{i}}{L E L_{i}}}
$$

oraz

$$
U E L_{\text {mieszaniny }}=\frac{\sum_{i=1}^{N} P_{i}}{\sum_{i=1}^{N} \frac{P_{i}}{U E L_{i}}}
$$

gdzie:

$P_{i}-$ udział $i$-tego gazu palnego w mieszaninie, $N$ - liczba gazów, 
$L E L_{i}$ - dolna granica zakresu palności $i$-tego gazu,

$U E L_{i}$ - górna granica zakresu palności $i$-tego gazu.

Wzory te pozwalają na podanie dolnej i górnej granicy zakresu palności mieszanin gazów palnych z powietrzem w standardowych warunkach ciśnienia i temperatury.

Temperatura, ciśnienie oraz stężenie utleniacza również wpływają na wartości graniczne zakresu palności mieszaniny. Wyższa temperatura i ciśnienie, jak również większe stężenie utleniacza (głównie tlenu w powietrzu) powodują obniżenie LFL i zwiększenie UFL, czyli wzrost zakresu palności mieszaniny.

\section{Spalanie mieszanin gazów palnych z azotem i innymi gazami niepalnymi}

W normie ISO 10156 podano metodykę określania palności mieszanin gazów zawierających gazy palne, niepalne i powietrze. W poprzednich rozdziałach omówiono zagadnienia palności mieszanin gazów palnych, nie rozpoznając wpływu gazów niepalnych na zakresy palności tych mieszanin. Każdy gaz obojętny obecny w mieszaninie gazów palnych powoduje zmianę dolnej i górnej granicy palności tej mieszaniny. Reakcja spalania powoduje ogrzanie gazów obojętnych w mieszaninie do temperatury płomienia, co zużywa część energii wydzielonej podczas reakcji spalania, a zatem wpływa na ciepło spalania i wartość opałową tych mieszanin. Niektóre gazy obojętne oddziałują dodatkowo na przebieg reakcji spalania. Wpływ zawartości gazu obojętnego w mieszaninie gazów na granicę zakresu palności uwzględniany jest przez wprowadzenie bezwymiarowej stałej $K$ zwanej ,współczynnikiem równoważności względem azotu”.

W normie ISO 10156 oraz w pracach Schrödera i Molnarne (2005) i Molnarne et al. (2005) podano nierówność empiryczną pozwalającą na określenie, czy mieszanina zawierająca gazy obojętne (niepalne) jest palna. Nierówność ta ma postać:

$$
\sum_{i=1}^{P} A_{i}\left(\frac{100}{T_{c_{i}}}-1\right) \leq \sum_{k=1}^{N} B_{k} K_{k}
$$

gdzie:

$A_{i}$ - wyrażona w procentach objętościowych zawartość $i$-tego gazu palnego w mieszaninie gazów palnych i niepalnych,

$P$ - liczba gazów palnych w mieszaninie, et al., 2005)
$B_{k}$ - wyrażona w procentach objętościowych zawartość $k$-tego gazu niepalnego w mieszaninie gazów palnych i niepalnych,

$N$ - liczba gazów niepalnych w mieszaninie,

$K_{k}$ - współczynnik uwzględniający wpływ $k$-tego gazu obojętnego na granice palności mieszaniny gazów (coefficient of nitrogen equivalency, czyli tzw. „współczynnik równoważności względem azotu”) (dla azotu $K=1$ ),

$T_{c_{i}}$ - maksymalna zawartość $i$-tego gazu palnego, dla której mieszanina tego gazu z azotem nie jest palna (wyrażona w procentach objętościowych).

Mieszaniny gazów, dla których powyższa nierówność jest spełniona, klasyfikowane są jako mieszaniny niepalne. Wartości współczynnika $T_{c}$ określone w odniesieniu do azotu na podstawie wykresów spalania dla gazów występujących w gazie ziemnym według różnych źródeł podano w tabeli $2 \mathrm{w}$ procentach objętościowych w standardowych warunkach ciśnienia i temperatury.

Jak widać z tabeli 2, wyniki badań mogą się znacznie różnić między sobą w zależności od źródła, które podaje $T_{c}$. Wynika to z zastosowania rozmaitych metod pomiarowych i rozmaitej aparatury. Przyjęto dane podane przez ISO 10156 z uwagi na fakt obowiązywania norm ISO w Polsce. Jak wynika z podanych

Tabela 2. Wartości współczynnika równoważności względem azotu $T_{c}$ według różnych źródeł (Yaws i Braker, 2001; Molnarne et al., 2005)

Table 2. Coefficients of nitrogen equivalency $T_{c}$ (Yaws and Braker, 2001; Molnarne

\begin{tabular}{|l|c|c|c|c|}
\hline Rodzaj gazu & $\begin{array}{c}\text { ISO } \\
\mathbf{1 0 1 5 6}\end{array}$ & $\begin{array}{c}\text { BAM (Bundesanstalt } \\
\text { für Materialfor- } \\
\text { schung, Niemcy) }\end{array}$ & $\begin{array}{c}\text { Uniwersytet } \\
\text { w Paderborn } \\
\text { (Niemcy) }\end{array}$ & $\begin{array}{c}\text { CHEMSAFE, } \\
\text { Niemcy } \\
\text { (dane zalecane) }\end{array}$ \\
\hline \hline Metan & 14,3 & 8,5 & 9,5 & 8,7 \\
\hline Etan & 7,6 & 4,5 & 4,6 & 4,5 \\
\hline Propan & 6,0 & 3,7 & 4,0 & 3,7 \\
\hline Butan & 5,7 & 3,6 & 3,8 & 3,6 \\
\hline Izobutan & 5,7 & 3,4 & 3,6 & 3,4 \\
\hline Pentan & 6,0 & 4,1 & 4,3 & 4,2 \\
\hline Izopentan & 5,9 & 4,1 & 4,4 & 4,3 \\
\hline Heksan & 5,5 & 5,7 & 5,3 & 6,0 \\
\hline Siarkowodór & 6,9 & 7,0 & 7,2 & 6,9 \\
\hline Wodór & 5,7 & 5,4 & 5,6 & 5,5 \\
\hline
\end{tabular}

danych (tab. 2) różnice pomiędzy wartościami $T_{c}$ według różnych źródeł dochodzą do 40\%. Współczynnik $K$ uwzględniający wpływ zawartości $k$-tego gazu obojętnego (niepalnego) na zakres granicy palności (wybuchowości) mieszaniny tego gazu $\mathrm{z} i$-tym gazem palnym w odniesieniu do azotu podano w tabeli 3 dla gazów występujących w gazie ziemnym. Dane odnoszą się do standardowych warunków ciśnienia i temperatury.

Wartość współczynnika $K$ równa na przykład 1,2 dla helu oznacza, że granica palności mieszaniny, np. metanu i helu, 
Tabela 3. Wartości współczynnika $K$ dla warunków standardowych $\left(20^{\circ} \mathrm{C}, 1\right.$ bar) (ISO 10156)

Table 3. Values of coefficient $K$ in standard conditions $\left(20^{\circ} \mathrm{C}, 1\right.$ bar) (ISO 10156)

\begin{tabular}{|l|c|c|c|c|c|}
\hline \multicolumn{1}{|c|}{ Gaz } & Argon & Neon & Hel & Azot & CO $_{2}$ \\
\hline \hline Metan & 0,62 & 0,93 & 1,20 & 1,0 & 2,27 \\
\hline Etan & 0,62 & 0,88 & 1,10 & 1,0 & 1,84 \\
\hline Propan & 0,65 & 0,81 & 1,04 & 1,0 & 1,87 \\
\hline Butan & 0,64 & 0,80 & 1,01 & 1,0 & 1,94 \\
\hline Izobutan & 0,59 & 0,77 & 1,01 & 1,0 & 1,84 \\
\hline Pentan & 0,60 & 0,71 & 1,01 & 1,0 & 1,93 \\
\hline Wodór & 0,75 & - & 1,62 & 1,0 & 1,51 \\
\hline Wartość do obliczeń & 0,59 & 0,77 & 1,01 & 1,0 & 1,84 \\
\hline
\end{tabular}

Tabela 4. Wielkości współczynnika równoważności względem azotu $T_{c}$ dla różnych temperatur (ISO 10156, ASTM E918)

Table 4. Nitrogen equivalency values $T_{c}$ for various temperatures (ISO 10156, ASTM E918)

\begin{tabular}{|l|c|c|c|c|}
\hline \multicolumn{1}{|c|}{$\mathbf{G a z}$} & $\mathbf{C O}_{\mathbf{2}}\left(\mathbf{2 0}^{\circ} \mathbf{C}\right)$ & $\mathbf{H}_{\mathbf{2}}\left(\mathbf{1 0 0}-\mathbf{1 1 0}^{\circ} \mathbf{C}\right)$ & $\mathbf{A r}\left(\mathbf{2 0}^{\circ} \mathbf{C}\right)$ & $\mathbf{H e}\left(\mathbf{2 0}^{\circ} \mathbf{C}\right)$ \\
\hline \hline Metan & 2,23 & 1,87 & 0,69 & 1,31 \\
\hline Etan & 1,87 & 1,40 & - & - \\
\hline Propan & 1,93 & 1,51 & - & - \\
\hline Butan & 1,84 & 1,68 & - & - \\
\hline Wodór & 1,51 & 1,35 & 1,62 & 1,62 \\
\hline Tlenek węgla & 1,26 & - & - & - \\
\hline
\end{tabular}

będzie 1,2 razy wyższa od granicy palności mieszaniny metanu i azotu, dla którego za punkt odniesienia przyjęto $K=1$. Duży wpływ na wielkość współczynnika $T_{c}$ ma temperatura otoczenia. W tabeli 4 podano przykładowe wielkości $T_{c}$ dla różnych temperatur i rozmaitych mieszanin gazów dla $K$ podanych w tabeli 3.

Jak powiedziano, wielkości współczynników $T_{c}$ i $K$ dla rozmaitych gazów różnią się znacznie w zależności od zastosowanej metodyki badań i w zależności od źródła, które je podaje. Przykładowo, wielkość $T_{c}$ mieszaniny metanu i azotu według ISO 10156 jest niemal dwukrotnie większa od wielkości podawanych przez inne źródła (BAM, Paderborn, CHEMSAFE) (Yaws i Braker, 2001), a zatem wszystkie obliczenia palności mieszaniny gazów lub jej braku należy traktować jako przybliżone, co wymaga zachowania odpowiedniego współczynnika bezpieczeństwa.

\section{Spalanie gazu ziemnego we flarze}

W przemyśle naftowym gaz ziemny spalany we flarze jest mieszaniną rozmaitych gazów, zarówno palnych, jak i niepalnych. Do gazów palnych należą przede wszystkim: metan, etan, propan, butany, pentany, heksan, siarkowodór, natomiast z gazów niepalnych występują: dwutlenek węgla, azot, hel. W przypadku obecności powietrza traktowane jest ono jako mieszanina azotu (70\%) i tlenu (30\%). W większości przypadków gaz ziemny jest gazem łatwopalnym, gdyż zawiera duże ilości metanu i jego spalanie we flarze nie napotyka na trudności. Niekiedy jednak skład gazu ziemnego jest nietypowy i mieszanina jego składników może okazać się niepalna lub oscylować wokół granicy palności. Uwaga ta dotyczy szczególnie gazów o wysokiej zawartości azotu. W Polsce do gazów wysokozaazotowanych należy gaz ze złóż Cychry, zawierający niekiedy ponad $80 \%$ azotu, oraz Sulęcin, gdzie zawartość azotu wynosi ponad $90 \%$. Obydwa te złoża znajdują się na Niżu Polskim, w pokładach cechsztyńskich w dolomicie głównym. Zaazotowany gaz ziemny wykorzystywany jest do produkcji ciekłego azotu lub korekty składu chemicznego gazu ziemnego przesyłanego krajowymi gazociągami. Zawartość składników palnych w takim gazie może okazać się niewystarczająca do efektywnego spalania go w standardowych warunkach ciśnienia i temperatury. W takich przypadkach do mieszaniny takich gazów doprowadzanych do flary wprowadzany jest dodatkowo gaz palny, najczęściej propan-butan, w celu umożliwienia procesu spalania, jeżeli skład mieszaniny nie mieścił się w zakresie palności (pomiędzy LEL a UEL) lub w celu poprawy efektywności procesu spalania.

$\mathrm{Z}$ uwagi na duże rozbieżności wielkości współczynników $T_{c}$ i $K$ podawanych przez różne źródła, różnorodność metod badań laboratoryjnych oraz niepewność otrzymywanych wyników do oceny natężenia dopływu doprowadzanego gazu propan-butan, w obliczeniach powinien być przyjmowany współczynnik bezpieczeństwa ustalany przez użytkownika urządzenia do spalania gazów. Przy ustalaniu palności mieszaniny gazów doprowadzanych do flary korzystać będziemy zatem z zależności (3), która aktualnie będzie miała postać:

$$
\sum_{i=1}^{P} A_{i}\left(\frac{100}{T_{c_{i}}}-1\right) \leq C \sum_{k=1}^{N} B_{k} K_{k}
$$

Jeżeli lewa strona nierówności (4) jest większa od prawej, oznacza to, że mieszanina gazów o danym składzie jest palna i można zutylizować ją we flarze bez potrzeby doprowadzania gazów propan-butan w celu poprawy efektywności spalania. W przypadku gdy nierówność (4) jest spełniona dla danej mieszaniny gazów, to przed przystąpieniem do spalania jej we flarze konieczne jest jej wzbogacenie przez doprowadzanie 
gazu palnego z zewnątrz, co wymaga wyposażenia flary w specjalną instalację doprowadzającą gaz propan-butan w pobliże końcówki flary. Wspomaganie spalania gazów we flarze jest szczególnie istotne, jeżeli spalany gaz zawiera siarkowodór, który jest gazem silnie trującym. Sposób obliczania natężenia przepływu doprowadzanego do flary gazu propan-butan umożliwiającego spalanie mieszaniny gazów we flarze podano za pracą Schrödera i Molnarne (2005).

\section{Algorytm obliczeń}

Na rysunku 2 przedstawiono algorytm obliczeń wymaganej dodatkowej ilości propanu-butanu koniecznej do całkowitego spalenia mieszaniny gazu. W algorytmie tym literami $L$ i $R$ oznaczono wartości wyrażeń nierówności (4) odpowiednio z lewej i prawej strony.

\section{Wyniki przykładowych obliczeń}

Przykładowe obliczenia wykonano dla gazów z dużą zawartością azotu, pochodzących z czterech polskich złóż. Przyjęto wartości współczynników $T_{c}$ i $K$ zalecane przez normę ISO 10156 (tab. 5).

Ze względu na rozbieżności ustalenia wielkości $T_{c}$ i $K$, które dochodzą do kilkudziesięciu procent, obliczenia wykonano dla dwóch wartości współczynnika bezpieczeństwa: $C=1,0$ oraz $C=1,5$. Przyjęto wydatek gazu ziemnego doprowadzanego do flary $Q=30 \mathrm{Nm}^{3} / \mathrm{min}$. W tabeli 6 podano z kolei składy poszczególnych gazów.

W tabeli 7 zestawiono wyniki obliczeń.

Tabela 5. Wartości współczynników $T_{c}$ i $K$

Table. 5. The values of $T_{c}$ and $K$ coefficients

\begin{tabular}{|l|r|r|}
\hline \multicolumn{1}{|c|}{ Rodzaj gazu } & $\mathbf{T}_{\mathbf{c}}$ & $\mathbf{K}$ \\
\hline \hline Metan & 14,3 & \\
\hline Etan & 7,6 & \\
\hline Propan & 6,0 & \\
\hline Butan & 5,7 & \\
\hline Izobutan & 5,7 & \\
\hline Pentan & 6,0 & \\
\hline Izo-pentan & 5,9 & \\
\hline Heksan & 5,5 & \\
\hline Siarkowodór & 6,9 & \\
\hline Dwutlenek węgla & & 2,27 \\
\hline Azot & & 1,00 \\
\hline Hel & & 1,31 \\
\hline Powietrze & & 1,20 \\
\hline
\end{tabular}

\section{START}

Wprowadzamy dane wejściowe:

- $Q$ - wydatek gazu doprowadzanego do flary

- $C$ - współczynnik bezpieczeństwa

- $A_{i}$ - udziały gazów palnych $(i=1,2, \ldots, P)$

- $B_{k}$ - udziały gazów niepalnych $(k=1,2, \ldots, N)$

- $T_{c i}$ - dla gazów palnych $(i=1,2, \ldots, P)$

$-K_{k}$ - dla gazów niepalnych $(k=1,2, \ldots, N)$

(gdzie $P$ i $N$ odpowiednio ilość gazów palnych i niepalnych)

$$
L=\sum_{i=1}^{P} A_{i}\left(\frac{100}{T_{c_{i}}}-1\right)
$$$$
R=C \sum_{k=1}^{N} B_{k} K_{k}
$$

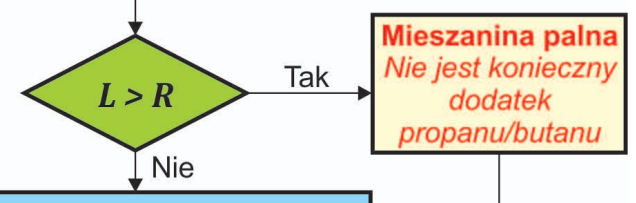

Mieszanina niepalna. Obliczamy:

stężenie propanu i butanu, przy

którym mieszanina jest palna

$\checkmark$

stężenie propanu

i butanu w mieszaninie

$\checkmark$

o ile należy zwiększyć zawartość

propanu i butanu w mieszaninie

Prezentacja wyników

STOP

Rys. 2. Uproszczony algorytm obliczeń

Fig. 2. Simplified calculation algorithm

Tabela 6. Składy gazów ziemnych z poszczególnych złóż

Table 6. Natural gas compositions for particular reservoirs

\begin{tabular}{|l|c|c|c|c|}
\cline { 2 - 5 } \multicolumn{1}{c|}{} & \multicolumn{4}{c|}{ Zloże } \\
\cline { 2 - 6 } \multicolumn{1}{c|}{ N } & C & C6 & M4 \\
\hline \hline Netan & 1,60 & 5,20 & 5,50 & 23,25 \\
\hline Etan & 0,40 & 1,30 & 2,87 & 6,18 \\
\hline Propan & - & - & - & 1,20 \\
\hline Pentan & 0,16 & 0,80 & - & - \\
\hline Izopentan & 0,11 & 0,76 & - & - \\
\hline Heksan & 0,09 & 0,72 & - & - \\
\hline Siarkowodór & - & - & 0,36 & 3,40 \\
\hline Dwutlenek węgla & 0,04 & 0,22 & 0,57 & 0,51 \\
\hline Azot & 97,60 & 91,00 & 90,7 & 65,46 \\
\hline
\end{tabular}


Tabela 7. Wyniki obliczeń

Table 7. Results of calculations

\begin{tabular}{|l|c|c|c|c|c|c|c|c|}
\hline \multicolumn{1}{|c|}{ Nazwa zloża } & \multicolumn{2}{c|}{ S } & \multicolumn{2}{c|}{ C } & \multicolumn{2}{c|}{ C6 } & \multicolumn{2}{c|}{ M4 } \\
\hline \hline Współczynnik bezpieczeństwa & 1 & 1,5 & 1 & 1,5 & 1 & 1,5 & 1 & 1,5 \\
\hline $\begin{array}{l}\text { Stężenie propanu i butanu, przy którym mieszanina } \\
\text { jest palna [\%] }\end{array}$ & 2,40 & 3,92 & 0,23 & 1,65 & 0,29 & 1,71 & 0,00 & 0,00 \\
\hline Obecna zawartość propanu i butanu w mieszaninie [\%] & 0 & 0 & 0 & 0 & 0,6 & 0,6 & 1,2 & 1,2 \\
\hline $\begin{array}{l}\text { O ile należy zwiększyć udział propanu i butanu, aby } \\
\text { mieszanina była palna [\%] }\end{array}$ & 2,40 & 3,92 & 0,23 & 1,65 & $\begin{array}{c}\text { brak } \\
\text { potrzeby }\end{array}$ & 1,11 & $\begin{array}{c}\text { brak } \\
\text { potrzeby }\end{array}$ & $\begin{array}{c}\text { brak } \\
\text { potrzeby }\end{array}$ \\
\hline $\begin{array}{l}\text { Wydatek dodatkowego propanu i butanu, aby miesza- } \\
\text { nina była palna [Nm\%/min] }\end{array}$ & 0,72 & 1,18 & 0,07 & 0,50 & $\begin{array}{c}\text { brak } \\
\text { potrzeby }\end{array}$ & 0,33 & $\begin{array}{c}\text { brak } \\
\text { potrzeby }\end{array}$ & $\begin{array}{c}\text { brak } \\
\text { potrzeby }\end{array}$ \\
\hline $\begin{array}{l}\text { Wydatek dodatkowego propanu i butanu, aby miesza- } \\
\text { nina była palna [kg/min] }\end{array}$ & 9,26 & 15,10 & 0,90 & 6,37 & $\begin{array}{c}\text { brak } \\
\text { potrzeby }\end{array}$ & 4,26 & $\begin{array}{c}\text { brak } \\
\text { potrzeby }\end{array}$ & $\begin{array}{c}\text { brak } \\
\text { potrzeby }\end{array}$ \\
\hline
\end{tabular}

\section{Podsumowanie}

W artykule przedstawiono sposób obliczania wydatku gazów propan-butan wymaganego do efektywnego spalania na flarze gazów niskometanowych z zawartością siarkowodoru oraz dużą zawartością gazów niepalnych. Ponieważ podawane przez różne źródła rozbieżności wielkości współczynników $T_{\mathrm{c}}$ i $K$ dochodzą do kilkudziesięciu procent, zatem należy stosować współczynnik bezpieczeństwa $(C>1,0)$, który zwiększa pewność całkowitego spalenia mieszaniny gazów. O wielkości przyjmowanego współczynnika bezpieczeństwa powinien decydować operator urządzenia do spalania gazów (flary) na podstawie wyników analizy dotychczasowych doświadczeń przemysłowych.

Przedstawiony sposób ustalania palności mieszanin gazów lub jej braku oraz wydajności mieszaniny propan-butan wymaganej do spalania oparty jest na zależnościach empirycznych i może być pomocny przy planowaniu wspomaganego spalania gazów ziemnych przy użyciu flary.

\section{Literatura}

Bertolino A., Stagnic A., Cuoci A., Faravelli T., Parente A., Frassoldati A., 2019. Prediction of flammable range for pure fuels and mixtures using detailed kinetics. Combustion and Flame, 207: 120-133. DOI: 10.1016/j.combustflame.2019.05.036.

Budak P., Szpunar T., 2020. Zmiany parametrów mieszaniny gazu ziemnego $\mathrm{z}$ wodorem $\mathrm{w}$ trakcie eksploatacji komory magazynowej w kawernie solnej. Nafta-Gaz, 11: 39-46. DOI: 10.18668/ NG.2020.11.05.

Chilcoat C., 2013. The Associated Effects of the Shale Gas Revolution. ENERPO Journal, 1.
Molnarne M., Mizsey P., Schröder V., 2005. Flammability of gas mixtures: Part 2: Influence of inert gases. Journal of Hazardous Materials, 121(1-3): 45-49. DOI: 10.1016/j.jhazmat.2005.01.033.

Schröder V., Molnarne M., 2005. Flammability of Gas Mixtures: Part 1: Fire Potential. Journal of Hazardous Materials, 121(1-3): 37-44. DOI: 10.1016/j.jhazmat.2005.01.032.

Szczypiorska A., 2015. Flara, pochodnia, świeczka - czy to tylko płomień nad rafinerią? $<$ https://infolupki.pgi.gov.pl/pl/technologie/flara-pochodnia-swieczka-czy-tylko-plomien-nad-rafineria> (dostęp: 04.08.2020).

Yaws C.L, Braker W., 2001. Matheson Gas Data Book. 7 edition. McGraw Hill Professional.

\section{Akty prawne i dokumenty normatywne}

ASTM E918-83 (1999) Standard practice for determining limits of flammability of chemicals at elevated temperature and pressure.

ISO 10156:2010 Gases and gas mixtures - Determination of fire potential and oxidizing ability for the selection of cylinder valve outlets.

Mgr inż. Paweł BUDAK
Starszy specjalista naukowo-badawczy,
kierownik Zakładu Inżynierii Naftowej
Instytut Nafty i Gazu - Państwowy Instytut Badawczy
ul. Lubicz 25 A
31-503 Kraków
E-mail: pawel.budak@inig.pl

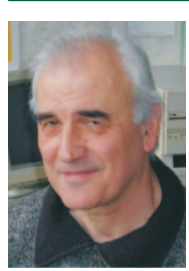

Dr inż. Tadeusz SZPUNAR

Adiunkt w Zakładzie Inżynierii Naftowej

Instytut Nafty i Gazu - Państwowy Instytut Badawczy ul. Lubicz 25 A

31-503 Kraków

E-mail: tadeusz.szpunar@inig.pl 